Volume 4

Number 2 Symposium Edition - Sustainable

\title{
Bringing Home the Right to Housing to Advance Urban Sustainability
}

Lisa Alexander

Texas A\&M University School of Law, Italexander@law.tamu.edu

Follow this and additional works at: https://scholarship.law.tamu.edu/journal-of-property-law

Part of the Housing Law Commons, and the Property Law and Real Estate Commons

\section{Recommended Citation}

Lisa Alexander, Bringing Home the Right to Housing to Advance Urban Sustainability, 4 Tex. A\&M J. Prop. L. 67 (2018).

Available at: https://doi.org/10.37419/JPL.V4.I2.1

This Symposia Article is brought to you for free and open access by Texas A\&M Law Scholarship. It has been accepted for inclusion in Texas A\&M Journal of Property Law by an authorized editor of Texas A\&M Law Scholarship. For more information, please contact aretteen@law.tamu.edu. 


\title{
Bringing Home the Right to Housing to Advance Urban Sustainability
}

\author{
Professor Lisa T. Alexander
}

The title of my talk today is Bringing Home the Right to Housing to Advance Urban Sustainability. You may ask what is the right to housing? Why do we need to bring it home? And what does it have to do with the broader topic of today's symposium, urban sustainability?

The human right to housing, although not a formal American federal or constitutional right, provides an important legal and normative framework that can help American cities and states better balance the needs of owners and non-owners in local housing and development struggles. If American cities and states want to create sustainable urban communities that will flourish for generations, they will need the human right to housing as one legal tool in their sustainability toolkit. If we understand the term urban sustainability to include not just the sustainability of the land, air, water, and spaces that humans occupy, but also the sustainability of the inhabitants and positive social relationships in urban spaces, then the human right to housing must become a part of cities' urban sustainability arsenal.

The right to housing is an international human right, enshrined in the constitutions of several countries and in the International Covenant on Economic, Social, and Cultural Rights ("The Covenant"). ${ }^{1}$ While the United States has signed the Covenant, Congress has not ratified it. Thus, the right to housing does not have the force of law in the United States. ${ }^{2}$ Yet, if ratified by Congress, the right to housing could provide America with a normative rubric to better balance private property rights and non-owners' housing needs. Even in the absence of federal legal adoption, cities and states can use the right to housing to help resolve housing and property challenges at the local level.

$\dagger$ Professor of Law, Texas A\&M University School of Law with a joint appointment in Texas A\&M University's Department of Landscape Architecture and Urban Planning; Co-Director, Texas A\&M University School of Law's Program in Real Estate and Community Development Law; Associate Professor, University of Wisconsin Law School; Research Affiliate, Texas A\&M University Center on Housing and Urban Development; and Research Affiliate, University of Wisconsin Institute for Research on Poverty. Many thanks to my research assistant, Nicholas Vail, for his help on this article and to the editors of the Texas A\&M University Journal of Property Law for their work on this keynote speech.

1. See International Covenant on Economic, Social and Cultural Rights art. 11, Dec. 16, 1966, S. Treaty Doc. No. 95-19, 6 I.L.M. 360 (1967), 993 U.N.T.S. 3 [hereinafter Covenant].

2. See Lisa T. Alexander, Occupying the Constitutional Right to Housing, 94 NeB. L. Rev. 245, 251-252 (2015).

DOI: https://doi.org/10.37419/JPL.V4.I2.1 
The human right to housing establishes that each person within a state signatory's borders has a right to "adequate housing." 3 The U.N Committee on Economic, Social and Cultural Rights interprets the Covenant to contain at least seven key elements: ${ }^{4}$

- Security of tenure: Every person must be able to occupy his or her home free from harassment, forced and illegal evictions, and other threats of displacement. Even legal evictions must be carried out with adequate due process protections, so as not to undermine humans' rights to adequate housing.

- Availability of services, materials, facilities and infrastructure: Housing should provide all residents access to essential facilities and services, such as safe drinking water, electricity, heating, sanitation, and cooking and washing facilities.

- Affordability: Steps must be taken to ensure that housing costs do not threaten humans' financial capacities to meet other basic needs.

- Habitability: Housing must be safe, healthy, and habitable, including adequate space, privacy, and protection from weather, disease, and structural hazards.

- Accessibility: Steps must be taken to ensure those with special needs, including persons with disabilities, the elderly, and persons who are terminally ill or HIV-positive, have ready access to housing.

- Cultural Adequacy: Housing and housing policy must allow for the expression of cultural identity and diversity.

- Location: Housing must be built away from polluted sites and other health and safety threats and in a location that provides access to jobs, healthcare, schools, and other human needs. ${ }^{5}$

The human right to housing's broad and affirmative statement of housing rights may sound anomalous to Americans, as our legal tradition has historically framed housing rights more narrowly. Yet, the human right to housing can provide American cities and states with housing goals that they can incorporate into their local laws, plans of action, and budgeting initiatives to advance housing rights for all people within their borders. This rubric can help localities devise and plan for new housing arrangements that are more equitable, sustainable,

3. See id. at 251.

4. See id. at 253 (Since 1986 the U.N. Committee on Economic, Social and Cultural Rights has produced statements that interpret the meaning and application of the Covenant based upon their monitoring experience. The Committee derived these seven principles).

5. See U.N. Comm. on Econ., Soc., \& Cultural Rights (CESCR), General Comment No. 4: The Right to Adequate Housing (Art. 11 (1) of the Covenant), E/1992/23 II 7 (Dec. 13, 1991), http://www.refworld.org/docid/47a7079a1.html [https://perma.cc/ T49W-BY44]. 
and economically efficient. The right to housing, then, can provide a balancing standard that localities can use to evaluate the efficacy of housing and development plans to advance both equity and efficiency in local housing markets.

Local and state governments that enact a right to housing do not need to provide everyone within their borders with a home, yet they need to endeavor to recognize the right to housing for all people within their borders by meeting minimum requirements such as:

- Progressive Realization: Governments must take steps to progressively realize this right for all, over time, through plans of action, budgeting initiatives, and partnerships with private sector organizations.

- Non-Retrogression: Governments must not regress in fulfilling these rights during difficult economic times or natural disasters.

- Maximum Available Resources: The Covenant provides that each state party should undertake steps to progressively achieve the right to housing for all to the "maximum of its available resources." Governments are not supposed to abandon their commitments to the right to housing during economic downturns.

- Minimum Core Content/Standards: The Covenant also provides that participating governments have minimum core obligations to ensure the satisfaction of at least minimum essential levels of each of the rights provided in the Covenant. ${ }^{6}$

Countries often fulfill these requirements through basic legislative and programmatic requirements. While in some countries these issues are justiciable, in others these goals are advanced through legislation and programmatic initiatives, rather than through litigation to enforce individual or group rights. ${ }^{7}$ When American localities use their traditional local government law powers to legitimate local-housing arrangements that reflect the right to housing, they bring the right to housing home to American soil, even in the absence of a formal legal right. Thus, the right to housing can serve as an important planning tool and balancing standard, empowering, rather than limiting, local governments to creatively meet future housing challenges for all of their residents.

6. See U.N. Office of the High Comm'r for Human Rights (OHCHR), The Right to Adequate Housing, Fact Sheet No. 21/Rev.1 (Nov. 2009) [hereinafter Fact Sheet No. 21], http://www.ohchr.org/Documents/Publications/FS21_rev_1_Housing_en.pdf [https://perma.cc/9CXJ-SY89].

7. Thomas Byrne \& Dennis P. Culhane, The Right to Housing: An Effective Means for Addressing Homelessness?, 14. U. PA. J.L. \& Soc. Change 379, 382 (2011) (explaining that the right to housing often serves as a mechanism to encourage states to engage in programmatic efforts that lead different abstract efforts to enforce the right). 
Some may ask why do we need to expand housing rights? Isn't education or health care more important? First, housing is, for most Americans, not only a primary source of refuge, but also their greatest expenditure. ${ }^{8}$ The location of your home can partially determine your quality of life: whether you graduate from high school and college, have access to healthy food and clean water, live in a safe and vibrant community, or obtain a job. ${ }^{9}$ For many owners, a home is a primary source of wealth building and wealth creation. ${ }^{10}$ Private property owners obtain a bundle of rights, including the ability to use, exclude, and transfer their housing, and often Americans exercise these rights with the main objective of increasing wealth. ${ }^{11}$ While wealth creation should remain an important function of housing, I argue that America's privileging of the wealth creating functions of housing above all other functions has led to an imbalanced system of housing provision that is fundamentally unsustainable.

Recent national statistics show that we have rising levels of housing unavailability and housing insecurity for an increasingly larger portion of the American populace. ${ }^{12}$ Over the last twenty years, the globalization and financialization of housing markets has led national, state, and local housing markets to privilege the wealth creating functions of housing above all other functions, making housing increasingly unavailable to moderate- and low-income people. ${ }^{13}$ "Global real estate

8. Press Release, Bureau of Labor Statistics, U.S. Dep't of Labor, Consumer Expenditures - 2015 (Aug. 30, 2016, 10:00 AM), https://www.bls.gov/news.release/pdf/ cesan.pdf [https://perma.cc/K4KQ-SD8C].

9. See generally Alex Sarabia, Moving to Opportunity: How Housing Policy Can Disrupt the Persistence of Poverty, Chicago Policy Review (Nov. 25, 2015), http:// chicagopolicyreview.org/2015/11/25/moving-to-opportunity-how-housing-policy-candisrupt-the-persistence-of-poverty/ [https://perma.cc/QX6L-MNRF] (explaining how children who grow up in "lower-poverty neighborhoods are more likely to attend college, less likely to become single parents, and have substantially higher incomes").

10. Editorial, Homeownership and Wealth Creation, N.Y. TIMES (Nov. 29, 2014), https://www.nytimes.com/2014/11/30/opinion/sunday/homeownership-and-wealth-crea tion.html?mcubz=0 [https://perma.cc/TSR5-9CG9].

11. Johnathan Klick \& Gideon Parchomovsky, The Value of the Right to Exclude: An Empirical Assessment, 165 U. PA. L. Rev. 917, 919-23 (2017) (explaining the right to exclude as a key right to advance efficiency and the "bundle of rights" concept and its role in property law and theory).

12. See Ester Bloom, A Shocking Number of Americans Live in Housing They Can't Afford, According to Harvard Study, CNBC Money (July 13, 2007), http:// www.cnbc.com/2017/07/13/harvard-study-heres-how-many-americans-cant-affordhousing.html [https://perma.cc/8EMB-9Y8G] (citing a recent 2017 study by the Joint Center for Housing Studies at Harvard University).

13. Leilani Farha, (U.N. Special Rapporteur on Adequate Housing), Report of the Special Rapporteur on Adequate Housing as a Component of the Right to an Adequate Standard of Living, and on the Right to Non-Discrimination in this Context, II 1, U.N. Doc. A/HRC/34/51 (Jan. 18, 2017), available at https://documents-dds-ny.un.org/doc/ UNDOC/GEN/G17/009/56/PDF/G1700956.pdf?OpenElement. ("[T]he "financialization of housing' refers to structural changes in housing and financial markets and global investment whereby housing is treated as a commodity, a means of accumulat- 
represents nearly 60 per cent of the value of all global assets or \$USD 217 trillion - with residential real estate comprising \$USD 163 trillion or 75 per cent. This represents more than twice the world's total GDP."14 The United States' housing expenditures also reveal ${ }^{15}$ that the bulk of public funds to support and facilitate housing markets support those arguably least in need of assistance-wealthy and middleclass home owners-thereby privileging the wealth-creating functions of housing over other functions. Housing, however, serves many other human needs besides wealth creation. Housing is shelter. It can be an integral part of one's sense of identity and purpose. It can be an individual's or a family's connection to community or place. It can serve as a gateway to opportunity or disadvantage. It can provide an outlet for human creativity and pride. Yet, the global financialization of housing markets, combined with a legal tradition of strong private property rights in the U.S., has made it increasingly difficult for nonowners and inexperienced, or first-time, homebuyers to secure longterm adequate housing.

The global financial crisis of 2008, and the following Great Recession, also vividly illustrated that housing provision generally, and affordable housing provision in particular, is an integral part of the American and global economies. The failure to deal with problematic aspects of housing finance-subprime mortgages, predatory lending, mortgaged backed securities, collateralized debt obligations ("CDOs"), and other national and internationally sold derivativesnearly brought the American Economy to its knees, in a manner we had not seen since the Great Depression. ${ }^{16}$ The crisis further demonstrated that relatively unregulated housing markets, which privilege the wealth creating function of housing above all other functions, led to unscrupulous and unsustainable housing practices and markets. America is still trying to recover from the ill effects of this unbalanced system. For example, in the wake of the financial crisis:

ing wealth and often as security for financial instruments that are traded and sold on global markets. It refers to the way capital investment in housing increasingly disconnects housing from its social function of providing a place to live in security and dignity and hence undermines the realization of housing as a human right.").

14. See id. at II 3 .

15. The U.S. spends roughly $\$ 46$ billion a year on affordable housing; $\$ 40$ billion on means-tested programs; $\$ 6$ billion in tax expenditures through the Low Income Housing Tax Credit (LIHTC) program; Compare that to $\$ 195$ billion in subsidies that flow largely to wealthy and middle class homeowners via tax deductions for mortgage interest. See generally Matthew Desmond, Evicted: Poverty and Profit in the AMERICAN City (2016).

16. See Adam J. Levitin \& Susan M. Wachter, Explaining the Housing Bubble, 100 GEO. L.J. 1177, 1181 (2012) (arguing that the American Housing Bubble was largely caused by an excessive supply of housing finance generated by a fundamental shift in the structure of the mortgage-finance market from regulated to unregulated securitization). 
- The United States homeownership rate declined to $64.5 \%$.

- The 35-44-year-old United States homeownership rate declined $5.4 \%$ points since 1993 .

- The United States minority homeownership rate was $25.4 \%$ points lower than that of whites.

- The greatest increase in failed United States homeownership spells, between 2009 and 2013, occurred among Hispanics.

- In 2014, the number of Hispanic and Asian homeowners increased as their total share of all households increased.

- United States homeownership still led to gains in household wealth, even during 1999-2013. ${ }^{17}$

While homeownership still contributed to household wealth, the crisis led to historic declines in the homeownership rate. ${ }^{18}$ Further, during the United States housing crisis, over the course of five years, "over 13 million foreclosures resulted in more than 9 million households being evicted."19

During the same period, between 2006 and 2014, the United States renter population grew in America's largest metro areas. ${ }^{20}$ The share of United States households who rent rose to $35.5 \%$, which is a 20 year high. This marks the tenth consecutive year of growth. Households in the top $50 \%$ of income distribution contributed $43 \%$ of the growth in renters. Households in the highest income quartile accounted for almost one-in-five net new renters between 2004 to 2014 and nearly one in three net new renters between 2011 to 2014. The growth occurred in the central cities and the surrounding suburbs, mirroring national trends-in 2014, there were nearly 22 million more people renting in metro areas in the United States than there had been in 2006, and while the renter populations within principal cities increased by more than nine million, the majority of the growth occurred outside of those cities. Indeed, the renter population in suburban areas outside principal cities grew by more than a third-more than 12 million people-between 2006 and $2014 .{ }^{21}$ Furthermore, there is a mismatch between supply and demand because the growth in the renter population exceeded the growth in rental stock. ${ }^{22}$ In the eleven

17. See generally Joint Center for Housing Studies of Harvard UniverSITY, The State of the Nation's Housing 2015 (2015), http://www.jchs.harvard.edu/sites/ jchs.harvard.edu/files/jchs-sonhr-2015-full.pdf [https://perma.cc/Y5YM-BGQM].

18. See id.

19. Farha, supra note 13, at IIII 3, 4.

20. See Ingrid Gould Ellen \& Brian Karfunkel, Renting in America's Largest Metropolitan Areas, NYU Furman Center \& Capital One 4 (Mar. 8, 2016), http:// furmancenter.org/news/press-release/national-affordable-rental-housing-landscape-inamericas-largest-metro-area [https://perma.cc/5NYG-3CLU].

21. See id.

22. See id. 
largest metros, the renter population grew more quickly than the number of rental housing units between 2006 and 2014. As rising demand for rental housing outpaced increases in supply, the market adjusted somewhat differently in each metro area. ${ }^{23}$ Single-family homes housed more than half of the renter growth between 2004 to $2013 .{ }^{24}$

The lowest income renters are the most rent burdened as demand for rental housing increases and the supply of low-income housing is inadequate to meet the demand. Further, housing subsidies in the form of vouchers, which subsidize privately-owned affordable housing or public housing, are also insufficient to meet demand. In America, " 67 percent-2 out of every 3 poor renting families-receive[s] no federal assistance." ${ }^{25}$ For those few families that do qualify to receive federal housing rental assistance, the waiting lists to obtain that assistance are long. In Milwaukee, the Housing Choice Voucher Program ("HCV") has a ten-year waiting list. In Chicago, as of 2014, HCV had been closed for four years. ${ }^{26}$

The lack of available affordable housing in many American cities also contributes to homelessness. ${ }^{27}$ Due to the concerted efforts of cities, states, and the federal government, through the U.S. Department of Housing and Urban Development, chronic homelessness among individuals in families declined 44\% from 2011 to 2016, while chronic homelessness among individuals not in families fell $25 \% .{ }^{28}$ Yet, homelessness amongst the non-chronic homeless population-families and individuals who have been homeless for less than a year or had experienced under four episodes of homelessness in the past three years totaling less than twelve months-only declined $8 \%$ during the same

23. See id.

24. See id.

25. $1 \%$ of poor residents lived in rent controlled units; $15 \%$ lived in public housing; $17 \%$ received a government subsidy, mainly in the form of a rent-reducing voucher; The remaining $67 \%-2$ of every 3 poor renting families-receives no federal assistance; $65 \%$ of closed HCV and $39 \%$ of closed public housing lists had been closed for more than a year. See Evicted, supra note 15, at 302-03.

26. See Lolly Bowean, Chicago Housing Authority Opens Wait Lists for Public Housing, Vouchers, Chicago Tribune (Oct. 27, 2014), http://www.chicagotribune. com/news/ct-cha-waiting-list-met-1028-20141027-story.html [https://perma.cc/A5W7$\mathrm{KCHC}]$.

27. See Why Are People Homeless?, National Coalition for the Homeless (July 2009), http://www.nationalhomeless.org/factsheets/why.html [https://perma.cc/ 5C68-F7RK].

28. See J.B. Wogan, While Homeless Veterans Get Housing, Rest are Left in the Cold, Governing (Feb. 2016), http://www.governing.com/topics/health-human-ser vices/gov-veteran-homelessness-obama-washington.html [https://perma.cc/5KEF7J6F]; See generally Office of Community Planning \& Development, U.S. Dep't of Housing \& Development, The 2016 Annual Homeless Assessment Report (AHAR) TO CONGREss 34 (Nov. 2016), https://www.hudexchange.info/resources/doc uments/2016-AHAR-Part-1.pdf [https://perma.cc/6UB4-D7LZ]. 
period. ${ }^{29}$ Researchers at the Joint Center for Housing Studies at Harvard University posit that homelessness amongst this population is most likely due to increases in housing costs and/or unanticipated expenses, changes in family structure, or sudden loss of income. ${ }^{30}$ They also propose that governments will need to employ a range of strategies to ameliorate homelessness in these cases, including emergency homelessness prevention and rapid-rehousing programs, and efforts to expand the affordable housing supply, improve households' financial stability and security, and provide stronger tenant protections. ${ }^{31}$

The current rate of housing unavailability and housing insecurity is unsustainable. Cities cannot continue to bear the increasing social and economic costs of more evicted households or homeless individuals who cannot secure adequate housing. This housing insecurity and unavailability undeniably negatively affects poor and moderate-income people, but it also generates negative spillovers and externalities for cities in the form of: the costs of homelessness and rising emergency room visits; the costs of more police for crime maintenance; and rising substance abuse. ${ }^{32}$ Cities are left to bear these costs eventually and these problems transcend municipal borders. The costly social problems that one city avoids inevitably spillover into neighboring cities and counties. If you are poor, the current American market, operating unchecked and without sufficient public support, simply does not provide enough adequate housing to lead to human flourishing. The current American market system without sufficient controls and subsidies is unsustainable for most urban cities.

Given that the right to housing is not a formal American legal right, how can cities use the human right to housing to forge more sustainable urban futures? I argue that the right to housing can serve as an important standard by which cities can determine which housing strategies best balance private property rights and human housing needs. Examples of property and housing arrangements that implicitly advance the right to housing abound in American cities. Dignity Village (the "Village") in Portland, Oregon was one of the first projects to progress from a homeless tent encampment to a village of tiny homes organized as a transitional village for the formerly homeless. The project was developed in 2001 on city-owned land in a public and private partnership with the city of Portland, formerly homeless residents, and

29. See id.

30. See id. See generally Ending Homelessness Today, National Alliance to END Homelessness (July 21, 2015), https://endhomelessness.org/report-affordablehousing-increasingly-unavailable-to-low-income-renters/ [https://perma.cc/LH3895RH] (discussing the Joint Center for Housing Studies at Harvard's findings).

31. Id. (discussing the need for a national commitment to affordable housing).

32. The Costs of Homelessness Facts, Green Doors, http://www.greendoors.org/ facts/cost.php [https://perma.cc/9S87-HA79] (last visited Sept. 20, 2017). 
housed volunteers. ${ }^{33}$ The Village is governed by an elected village council that includes formerly homeless village residents. ${ }^{34}$ As indicated by its name, Dignity Village is designed to not only provide shelter, but also to restore dignity to formerly homeless people by connecting them to others and giving them a meaningful role in their self-determination. Although the creators of Dignity Village do not claim their effort to be an expression of the right to housing, they organized the village in a way that advances the right to housing. Eugene, Oregon was one of the first cities to declare itself a HumanRights-City in 2011, and it implemented an ambitious homelessness prevention and tiny-homes-for-the-homeless initiative that furthers the right-to-housing for formerly homeless individuals. The Eugene tiny homes village is called Opportunity Village, and it was developed in close collaboration with a non-profit developer and the City of Eugene, Oregon. These initial projects have led to many other efforts to build tiny-homes-for-the-homeless projects in Oregon that serve as longer term and more stable housing options for formerly homeless people, such as Emerald Village and Square One Villages. ${ }^{35}$

Dane County, Wisconsin also enacted a right-to-housing resolution, and Madison, Wisconsin, situated in Dane County, made a zoning change to allow for tiny homes on wheels and approved a special planned unit development to zone a tiny homes village for the homeless in Madison, Wisconsin. The city initially closed down a homeless tent encampment, but with pressure from activists and organizers who purchased land on which to build a tiny-house community, the city approved a planned unit development zoning change to legalize tiny home villages. ${ }^{36}$ Initially, homeowners and residents in the area expressed some typical not-in-my-backyard (NIMBY) resistance to the creation of a tiny homes village in Madison, Wisconsin. However, once the homeless and volunteer coalition built the first home and began to show the productive and peaceful contributions they were making to what was once an abandoned auto shop, community resistance began to wane and city-residents began to volunteer to help bring the project to fruition. ${ }^{37}$ Architects, lawyers, and contractors

33. Andrew Heben, Tent City Urbanism: From Self-Organized Camps to Tiny House Villages 134-35 (2014).

34. See id.

35. See Andrew Heben, 2016 in Review: The Next Wave of Villages Take Root, Tent City Urbanism (Dec. 30, 2016), http://www.tentcityurbanism.com/2016/12/ 2016-in-review-next-wave-of-villages.html [https://perma.cc/32B8-PZMH].

36. Lisa T. Alexander, Occupying the Right to Housing, 94 NeB. L. Rev. 245, 286-88 (2015).

37. Doug Erickson, One Year in, Madison's village of tiny houses wins over many neighborhood critics, Wisconsin STATE Journal (Sept. 27, 2015), http:// host.madison.com/wsj/news/local/one-year-in-madison-s-village-of-tiny-houses-wins/ article_6d1a54cc-343a-5775-b3de-5fa341677580.html [https://perma.cc/UN6X-2KNS]. 
volunteered or donated their labor. ${ }^{38} \mathrm{OM}$ build, a non-profit organization, owns the land, and occupants pay rent through sweat equity. Residents participate in gardening or woodworking projects, the products of which are sold to the general public. ${ }^{39}$ The Madison tinyhomes-for-the-homeless example demonstrates how cities can enact the right to housing, through declarations, resolutions, zoning changes, or ordinances, and then support housing and property formulations that reflect the principles of the right to housing.

Seattle, Washington, has also embraced the tiny homes village concept as a temporary solution to escalating homelessness. Seattle does not explicitly use the language of the right to housing as a justification for its city-sponsored and supported projects, but its tiny-homes-forthe-homeless projects demonstrate how tiny homes can be used to advance the principles embodied in the right to housing. Quixote Village is one of the State of Washington's first tiny house villages opened in 2013 in Olympia, Washington, providing 30 tiny homes, each at 144 square feet, as temporary shelter for the homeless. ${ }^{40}$ Each tiny home in the village has "a toilet, a bed, a sink and a front porch facing out on the shared green space, which is dotted with trees and flowers. A nearby community center holds a large shared kitchen and showers, and a separate space for watching television, holding meetings or participating in the weekly yoga class." ${ }^{41}$ Since that project launched, the city rightfully declared a state of emergency regarding homelessness in 2015, and it has approved at least five city-sanctioned tiny house village sites developed in collaboration with a non-profit organization, the Low Income Housing Institute. ${ }^{42}$ The initial three tiny homes villages consist of temporary tiny homes or tent villages that house approximately 160 people at any time. ${ }^{43}$ Compared to living on the streets, these villages provide the homeless with increased habitability and community. The non-profit developer, the Low Income Housing Institute, provides management services to the villages. ${ }^{44}$ Thus, the villages are structured to meet more of the adequate housing standards embodied in the right to housing than life in a shelter or on the streets.

38. See id. at 288

39. See id. at 289.

40. Matt Mills McKnight \& Aileen Imperial, The Tiny-House Village That Started a Movement, KCTS9 (June 28, 2017), https://kcts9.org/programs/in-close/tiny-housevillage-started-movement [https://perma.cc/J2XA-WST2].

41. Id.

42. See e.g. McKnight \& Imperial, supra note 40; Sharon Lee, Tiny Houses: A Big Help for the Homeless, Crosscut (Jan. 4, 2017), http://crosscut.com/2017/01/tinyhouses-seattle-homeless/ [https://web.archive.org/web/20170105182917/http://crosscut.com/2017/01/tiny-houses-seattle-homeless/].

43. See Lee, supra note 42.

44. Arianna Bennett, Reno Looks to Seattle's Tiny Houses for Homeless Solution, KTVN-TV (June 14, 2017), http://www.ktvn.com/story/35595327/reno-looks-to-seat tles-tiny-houses-for-homeless-solution [https://perma.cc/WS9T-NFCY]. 
"Each location has a city mandated Community Advisory Committee (CAC) comprised of neighbors, businesses, and church groups who monitor progress, give feedback, and lend support." 45 Each site also has social workers who work with the formerly homeless residents to connect them to more permanent housing opportunities, a job, and education. The Mayor of Seattle helped the City develop and approve landmark legislation which legalized these encampments. In December of 2016, the Mayor of Seattle "announced the establishment of three new homeless encampment sites in Licton Springs, Georgetown and Myers Way in West Seattle."46 These projects are slated to be completed in 2017 and will serve over 200 individuals. These projects are designed to prioritize homeless people who are currently living in dangerous and unsafe locations on Seattle's streets and sidewalks. ${ }^{47}$

Beyond these examples, other cities have begun to embrace tiny homes as a solution to different kinds of homelessness and affordable housing shortages for the hard-to-house. There are tiny- homes-villages-for-the-homeless, either completed or underway, in Austin, Dallas, and Denton, Texas, each serving different populations of the homeless and providing more or less services to the homeless. Tinyhomes-for-the-homeless projects are under way in other parts of Seattle and in Tacoma, Washington. Detroit, Michigan has a tiny homes village. ${ }^{48}$ In Kansas City, Missouri, a tiny home village for homeless veterans is in the planning stages. ${ }^{49}$ The City Council of Oakland, California, approved a tiny homes project for homeless youth. ${ }^{50}$ And many other projects are underway in many other cities in America.

While tiny-homes-villages-for-the-homeless are examples of how cities can embrace housing and property arrangements that advance the right to housing, this idea will not work for all people in all cases. It can be a good alternative to life on the streets, but other forms of affordable and supportive housing are needed for the homeless and others who need assistance. The right to housing can be applied in other cases of housing as well. For example, Seattle, Washington has

45. See Lee, supra note 42.

46. See id.

47. See id.

48. Maureen Feighan, Public Gets First, Only Peek at Detroit Tiny Homes, The Detroit News (May 25, 2017, 4:22 PM), http://www.detroitnews.com/story/news/lo cal/detroit-city/2017/05/25/tiny-homes-tour/102157990/ [https://perma.cc/P3DEA4FX].

49. Rick Montgomery, Tiny Houses For Veterans: Upstart Project Moves Ahead, Ruffling Some in Old Guard, The Kansas City Star (Mar. 30, 2017, 7:00 AM), http://www.kansascity.com/news/business/development/article141538624.html [https:// perma.cc/T7V2-ZK3X].

50. Mark Hedin, Oakland OKs Tiny Homes, Homeless Youth Housing Plans, THE Mercury News (Feb. 23, 2017, 10:15 PM), http://www.mercurynews.com/2017/02/23/ 4596099/ [https://perma.cc/Z7HV-3CLZ]. 
also embraced transferable development rights to protect existing affordable stock in order to give private owners of expiring affordable housing the option to keep the expiring housing affordable by transferring their unused potential to a city-run transferable development rights bank, or to other surrounding properties. ${ }^{51}$ San Francisco, California has condo-conversion laws and relocation funds that provide first rights of refusal to purchase, lengthy notice of evictions, and relocation costs. ${ }^{52}$ Milwaukee, Wisconsin has undertaken nuisance and building-code reassessments to reevaluate laws that force landlords to evict victims of a domestic-violence incident. ${ }^{53}$ All of these efforts can be understood as advancing the right to housing and ameliorating housing problems at the local level.

While the right to housing may not become a national American legal right in the near future, cities should consider how the right to housing can help advance urban equity and sustainability at a time of housing shortage and dwindling resources. As Eleanor Roosevelt once said in 1958 on the tenth anniversary of the Universal Declaration of Human Rights:

"Where, after all, do universal human rights begin? In small places, close to home-so close and so small that they cannot be seen on any maps of the world .... Unless these rights have meaning there, they have little meaning anywhere. Without concerned citizen action to uphold them close to home, we shall look in vain for progress in the larger world." 54

Thank you.

51. Incentive Zoning for Affordable Housing, SeAttle Office of Housing, https://www.seattle.gov/housing/housing-developers/incentive-zon-

ing\#nonresidentialdevelopment [https://perma.cc/YD4D-FAZC] (last visited Sept. 25, 2017).

52. Tenant Evictions in San Antonio, MC Hall \& Associates, http:// www.mhalllaw.com/PracticeAreas/Tenant-Evictions.asp [https://perma.cc/RKR728N8] (last visited Sept. 25, 2017).

53. DESMOND, supra note 15 at 190-192, 372-375.

54. Eleanor Roosevelt, Address at the United Nations: The Great Question (Mar. 27, 1958). 